\title{
MENINGKATKAN KEMAMPUAN BEKERJASAMA ANAK USIA 5-6 TAHUN MELALUI METODE BERMAIN KOOPERATIF
}

\author{
Indah Rinukti Prabandari $^{1}$; Fidesrinur $^{1}$ \\ ${ }^{1}$ Program Studi Pendidikan Guru Pendidikan Anak Usia Dini, Fakultas Psikologi dan Pendidikan, \\ Universitas Al-Azhar Indonesia, Jalan Sisingamangaraja, Kebayoran Baru, Jakarta Selatan 12110 \\ Penulis untuk Korespondensi/ E-mail: fideza@uai.ac.id
}

\begin{abstract}
Abstrak - Penelitian ini bertujuan untuk meningkatkan kemampuan bekerjasama anak, khususnya usia 5-6 tahun. Kemampuan berjasama merupakan hal penting untuk anak karena kemampuan bekerjasama dapat menjadi bekal anak untuk hidup di dalam masyarakat. Kemampuan bekerjasama rendah karena rata-rata di tiap sekolah kurang memperkenalkan bermain secara kelompok. Penelitian ini bertujuan untuk meningkatkan kemampuan bekerjasama melalui metode bermain kooperatif. Jenis penelitian ini adalah Penelitian Tindakan Kelas dan tempat penelitian ini berlokasi di PAUD Ceria, Cikarang Baru. Subjek penelitian terdiri dari 8 anak kelompok B. Hasil penelitian siklus pertama dan siklus kedua sebanyak $33 \%$. Pada kegiatan anak mau membuat secara bersama-sama sebesar 29\%; pada kegiatan anak tidak memilih-milih teman, sebesar 46\%; pada kegiatan anak mau berbagi, bergantian, mengoper secara bersama-sama, sebesar 38\%; pada kegiatan anak mau menghargai guru dalam menjelaskan cara dan peraturan, sebesar 38\%; pada kegiatan anak mampu untuk bersabar, sebesar 54\%; pada kegiatan anak mengambil balok, tidak melepas tangan, tidak memindahkan, sesuai peraturan, sebesar 38\%; pada kegiatan anak tidak menjatuhkan balok temannya, keluar dari lingkaran, tidak menjatuhkan karet temannya, sebesar $42 \%$; pada kegiatan anak melakukan kegiatan dengan tuntas, sebesar 33\%; pada kegiatan anak menempatkan balok, dan membuang sampah ke tempatnya, sebesar $12 \%$. Dari hasil penelitian tersebut dapat disimpulkan bahwa metode bermain kooperatif dapat meningkatkan kerjasama anak.
\end{abstract}

Kata kunci: Bermain, Kooperatif, KemampuanBekerjasama, Anak

Abstract - This study aims to improve the ability to cooperate with children, especially those aged 5-6 years. The ability to cooperate is important for children because the ability to cooperate can be a provision for children to live in society. The ability to cooperate is low because on average in each school there is less introduction to playing in groups. This researcher aims to improve the ability to cooperate through cooperative play methods. This type of research is Classroom Action Research and the research site is located in PAUD Ceria, CikarangBaru. The research subjects consisted of 8 children in group B. The results of the first cycle and the second cycle were 33\%. In the activities of children, they want to make 29\% together, in the activities of children they do not choose $46 \%$ of friends, in the activities of children they want to share, take turns, pass together 38\%, in children's activities they value the teacher in explaining ways and regulations $38 \%$, in the activities of the child being able to be patient 54\%, in the activities of the child taking the beam, not removing the hand, not moving, according to the regulation 38\%, in the activity the child did not drop his friend's beam, out of the circle, did not drop his rubber $42 \%$, at children's activities carry out activities thoroughly $33 \%$, in the activities of children placing blocks, and throwing garbage into place $12 \%$. From the results of these studies it can be concluded that the cooperative play method can improve children's collaboration.

Keywords: Play, Cooperative, Ability to Cooperate, Children 


\section{PENDAHULUAN}

$\mathrm{K}$ emampuan bekerjasama sangat penting dikembangkan pada anak sejak usia dini agar anak menjadi individu yang mampu bersosialisasi, berinteraksi, memiliki rasa toleran, menghargai, berbagi satu sama lain untuk mencapai tujuan bersama. Untuk itu orang tua dan orang dewasa di sekitar anak harus memberikan bimbingan dan arahan kepada anak untuk mempersiapkan anak memasuki lingkungan yang baru.

Anak usia 3 tahun akhir atau 4 tahun sudah mulai menunjukkan kemampuannya dalam bekerjasama dengan anak yang lain. Pada Permendikbud RI Nomor 137 Tahun 2014 tentang Standar Nasional Pendidikan Anak Usia Dini disebutkan bahwa kemampuan bekerjasama termasuk dalam aspek perkembangan sosial emosional anak usia 5-6 tahun, yang terlihat dalam bentuk bersikap kooperatif dengan teman; mentaati aturan kelas, bertanggungjawab; bermain dengan teman sebaya; mengetahui perasaan temannya, berbagi dengan orang lain; menghargai hak/ pendapat/ karya orang lain; menggunakan cara yang diterima sosial untuk menyelesaikan masalah; dan menunjukkan sikap toleran.

Hal ini juga dapat terlihat dalam kehidupan sehari-hari anak ketika bermain bersama di sekolah, contohnya, ketika anak bermain di luarkelas, merapihkan mainan bersama-sama, membantu guru merapihkan kelas. Kemampuan bekerjasama ini penting dilatih sejak dini, karena anak-anak lebih mudah menerima rangsangan dari stimulus yang diberikan. Stimulus itu bukan hanya dari guru saja tetapi dapat juga dari teman sebaya. Dimana teman sebaya juga dapat menjadi teman saling belajar. Ini berarti bahwa keberhasilan dalam belajar bukan hanya dari guru saja melainkan bisa juga dari teman sebaya. (Asteria, dkk, 2008: 2).

Ketidakmampuan anak dalam bekerjasama masih sering ditemui saat ini, seperti contoh ketika masih banyaknya anak yang tidak mau berbagi mainan, bahkan sampai menjauhkan temannya jika temannya tidak mau berbagi. Hal tersebut akan menyebabkan kelak anak menjadi sulit bersosialisasi dengan lingkungan. Contoh lainnya adalah masih banyak anak yang tidak mau bergabung bersama temannya ketika bermain, anak seringkali mengatakan aku main sendiri aja, aku gak mau main sama dia karena dia galak sama aku. Hal tersebut menunjukkan bahwa anak masih belum dapat menyelesaikan masalah sederhananya sendiri.

Selain itu, berdasarkan penelitian yang dilakukan oleh Aprilia Dian pada tahun 2017 yang berjudul Peningkatan Kerjasama Anak Melalui Permainan Kooperatif Pada Anak Kelompok B di TK ABA Ploso Kerep Bunder Patuk Gunung Kidul, disebutkan bahwa tingkat kemampuan kerjasama anak masih rendah, terdapat 9 anak dari 15 anak (60\%) mengalami kesulitan dalam kerjasama anak dalam hal berbagi dan berinteraksi.

Berdasarkan hasil observasi yang telah dilakukan di Kelompok B PAUD Ceria, Cikarang Baru, pada tanggal 23-27 Juli 2018, tentang kemampuan kerjasama, dengan tema Diriku, anak melakukan kegiatan membereskan kelas. Kegiatan ini diperintahkan oleh guru terlebih dahulu. Sekitar 6 dari 8 anak (75\%) belum melakukan kegiatan menuangkan air ke dalam ember, sedangkan 2 dari 8 anak (25\%) sudah mulai menunjukkan perilaku bekerjasama. Pada saat mengangkat meja dan kursi belajar secara bersama-sama hanya 2 dari 8 anak (25\%) yang mau mengangkat meja dan kursi belajar bersama temannya. Sekitar 5 dari 8 anak $(62.5 \%)$ belum mau bermain bersama, mereka masih memilih bermain sendiri.

Berdasarkan pengamatan dapat diketahui bahwa masih rendahnya kemampuan bekerjasama anak disebabkan diantaranya karena kurang diberikannya kegiatan bermain secara berkelompok. Salah satu solusi yang dapat digunakan untuk meningkatkan kemampuan bekerjasama pada anak adalah melalui metode bermain kooperatif. Permainan adalah salah satu cara untuk membuat kegiatan pembelajaran lebih menarik, menyenangkan dan dilakukan oleh anak secara sukarela.

\section{Kemampuan Bekerjasama}

Umur 2 sampai 6 tahun, anak belajar melakukan hubungan sosial dan bergaul dengan orang-orang di luar rumah, terutama dengan anak yang umurnya sebaya. (Nasution, 2010: 32). Kemampuan bekerjasama yaitu, anak mau bekerjasama dengan kelompok. Anak yang berusia dua atau tiga tahun belum berkembang kemampuan bekerjasamanya, mereka masih 
kuat dalam sikap self centered nya. Pada usia enam atau tujuh tahun, kemampuan bekerjasama ini sudah berkembang dengan lebih baik lagi. Pada usia ini anak mau bekerja kelompok dengan teman-temannya. (Nasution, 2010: 31).

Bekerjasama menurut Yusuf (2004: 125) adalah kemampuan mau bekerjasama dengan kelompok. Kemampuan mau bekerjasama artinya dapat diajak dalam menyelesaikan sesuatu (kegiatan) secara bersama dalam suatu kelompok. Hurlock (1978: 268), menuliskan bahwa bekerjasama merupakan kemampuan bekerja bersama menyelesaikan suatu tugas dengan orang lain. Dalam proses bekerjasama, anak dilatih untuk dapat menekan kepribadian individual dan mengutamakan kepentingan kelompok. Dari satu sisi anak memiliki sikap dalam melakukan kegiatan bersama dengan teman sebayanya, adanya sikap seperti itu anak mempunyai semangat bermain secara berkelompok.

Menurut Rheta De Vries (dalam Miftahul, 2016: 248), anak-anak mampu bekerjasama secara efektif asalkan guru dapat membangun lingkungan kelas yang suportif, mencontohkan skill kooperatif, dan berelasi secara personal dan positif dengan mereka. Menurut Charles $\mathrm{H}$. Cooley (dalam Sugiharyanto, 2007: 49), bekerjasama adalah usaha bersama antar individu atau kelompok untuk mencapai tujuan bersama.

Kemampuan bekerjasama timbul apabila orang menyadari bahwa mereka mempunyai kepentingan-kepentingan yang sama dan pada saat yang bersamaan mempunyai cukup pengetahuan dan pengendalian terhadap diri sendiri untuk memenuhi kepentingannya. Menurut Julia (2017: 53), kemampuan bekerjasama adalah kegiatan atau usaha yang dilakukan oleh beberapa orang untuk mencapai tujuan bersama dan menumbuhkan ikatan batin diantara teman lainnya tidak hanya teman karibnya saja.

Di dalam Permendikbud Nomor 137 Tahun 2013 pada aspek perkembangan sosial emosional anak usia 5-6 tahun terdapat indikator anak mentaati aturan kelas, bertanggungjawab, bermain dengan teman sebaya, mengetahui perasaan temannya, berbagi dengan orang lain, mengharga pihak/ pendapat/ karya orang lain, menggunakan cara yang diterima sosial untuk menyelesaikan masalah, bersikap kooperatif dengan teman, dan menunjukkan sikap toleran.

Dari beberapa definisi di atas maka yang dimaksud dengan kemampuan bekerjasama adalah suatu kemampuan mau bekerja dengan orang lain atau kelompok, usaha bersama antar individu atau kelompok untuk mencapai tujuan bersama. Setiap anak dilatih untuk mengutamakan kepentingan kelompok dan mengesampingkan kepentingan pribadi. Perbedaan-perbedaan yang terdapat pada diri anak dalam suatu kelompok dapat dijadikan sebagai kekuatan yang besar. Anak diberi kesempatan untuk memperoleh kesempatan berinteraksi sosial yang luas dan beraneka ragam yang diberikan oleh sekolah.

Ciri-ciri seorang anak dapat bekerjasama menurut Sears, dkk (1985: 118) adalah ketika anak tersebut: dapat bergabung dalam permainan kelompok; dapat terlibat aktif dalam permainan kelompok; bersedia berbagi dengan teman-temannya; mendorong anak lain untuk membantu orang lain; dan merespon dengan baik bila ada yang menawarkan bantuan.

Saputra dan Rudyanto (2005: 43-44) menyatakan empat langkah tahap kemampuan bekerjasama yakni: bekerja sendiri; mengamati dan mengenal lingkungan; merasa tertarik dan mengadakan penyesuaian diri; dan terbuka untuk memberi dan menerima. Adapun Langkah-langkah untuk menumbuhkan kemampuan bekerjasama menurut Musfiroh (2007: 20-22) adalah sebagai berikut: mengenalkan permainan yang bersifat kerjasama; mengenalkan kasih saying; mengenalkan sikap gotong royong; mengajarkan anak untuk berbagi; Mendorong anak untuk membantu; Mengajarkan kesungguhan hati dalam membantu orang lain.

Manfaat kemampuan bekerjasama adalah mampu mengembangkan aspek moralitas dan interaksi sosial anak karena melalui bekerjasama anak memperoleh kesempatan lebih besar untuk berinteraksi dengan anak lain, mempersiapkan anak untuk belajar bagaimana cara mendapatkan pengetahuan dan informasi sendiri baik dari guru, teman bahan pelajaran atau sumber belajar, meningkatkan kemampuan anak untuk bekerjasama dengan orang lain 
dalam sebuah tim, membentuk pribadi yang terbuka dan menerima perbedaan yang terjadi, dan membiasakan anak untuk selalu aktif dan kreatif dalam mengembangkan analisanya (Suyanto, 2005: 120).

\section{Pengertian Bermain}

Bermain pada dasarnya merupakan suatu kebutuhan bagi anak. Bermain bagianak merupakan suatu aktivitas yang sangat menyenangkan dan merupakan suatu cara anak belajar segala sesuatu yang ada di lingkungan sekitar. Bermain menurut Morison (dalam Rasyid, 2009: 78) merupakan bagian yang sangat penting dari kehidupan anak dalam masa-masa tumbuh kembang mereka, bermain menjadikan anak memiliki banyak pengalaman dalam hidupnya.

Bermain pada anak usia dini adalah aktivitas fisik dan psikis yang melibatkan pancaindra, terutama pendengaran dan penglihatan, serta melibatkan otak. Substansi bermain bagi anak usia dini adalah menyenangkan, bergembira, rileks, ceria, sukacita, mendidik, serta menumbuhkan aktivitas dan kreativitas. Bermain akan melibatkan berbagai aktivitas sensorimotor anak. Bermain membantu anak dalam mencapai perkembangan yang utuh baik perkembangan fisik, sosial-emosional, bahasa, kognitif, dan moral anak. (Rasyid, 2009: 76). Sedangkan menurut pendapat Kamtini dan Tanjung (2005: 48), bermain merupakan suatu kegiatan yang dilakukan anak secara sendirian maupun berkelompok baik menggunakan alat atau tanpa alat, dengan perasaan yang gembira.

Bermain merupakan hal yang paling menyenangkan untuk anak sehingga anak menjadi aktif, kreatif, dan inovatif. Hal tersebut dapat terjadi karena anak terlatih sejak dini. Menurut Ismail (2006: 18) bermain memiliki manfaat positif bagi anak yaitu:

1. Sarana untuk membawa anak ke dalam bermasyarakat.

Dalam suasana permainan anak saling mengenal satu sama lain, saling menghargai, dan perlahan-lahan timbul rasa kebersamaan yang menjadi landasan bagi pembentukan perasaan sosial.

2. Untuk mengenal kekuatan sendiri.
Anak-anak yang terbiasa bermain dapat mengenal kedudukannya di kalangan teman-temannya, serta dapat mengenal bahan dan sifat-sifat benda yang mereka mainkan.

3. Dapat melatih untuk mereda emosi.

Ketika bermain seorang anak akan mengalami bermacam-macam emosi, ada perasaan senang, ada perasaan kecewa. Hal ini yang akan menjadi pengalaman emosi bagi anak.

Mildred Parten (dalam Asmawati, 2011: 48) menyoroti bahwa kegiatan bermain sebagai sosialisasi dan ia mengamati ada 6 fase bentuk interaksi antar anak yang terjadi saat mereka bermain. Ada pun tahapan perkembangan kegiatan bermain bagi anak usia dini dikaitkan dengan fase-fase perkembangan sosial anak usia dini adalah sebagai berikut:

1. Unoccupied Play atau bermain sendiri hanya mengamati.

2. Onlooker Play atau bermain sebagai pengamat/ penonton.

3. Solitary Play atau bermain sendiri.

4. Pararel Play atau bermain pararel.

5. Associative Play atau bermain asosiatif.

6. Cooperative Play atau bermain bersama.

Tahap perkembangan bermain di dalam penelitian ini difokuskan pada tahap perkembangan bermain cooperative play, dimana tahap ini mulai terlihat pada anak usia 5 tahun dan bermain ini adalah jenis bermain dengan kelompok bersama teman-temannya. Jenis permainan kerjasama yang digunakan dalam penelitian ini adalah bermain kooperatif.

\section{Bermain Kooperatif}

Bermain kooperatif adalah bermain yang menggunakan kelompok kecil, sehingga mereka dapat menjalin kerjasama untuk memaksimalkan kelompoknya dan masingmasing melakukan pembelajaran. Bermain kooperatif juga merupakan rangkaian kegiatan belajar yang dilakukan oleh siswa dalam satu kelompok.

Bermain kooperatif menurut Parten (dalam Papalia, dkk, 2008: 387), adalah bermain di dalam kelompok yang terorganisir; untuk mencapai tujuan tertentu, misalnya untuk membuat sesuatu; bermain permainan formal 
atau mendramatisir; satu atau dua anak mengontrol anggota kelompok dan mengarahkan aktivitas. Menurut Patmonodewo (2000: 106), bermain kooperatif ialah dimana masing-masing anak memiliki peran tertentu guna mencapai tujuan kegiatan bermain.

Bermain kooperatif adalah cara yang digunakan anak dalam mengenal serta belajar berkomunikasi dan bersosialisasi dengan lingkungan permainannya untuk mencapai tujuan. Sejalan dengan pendapat di atas, bermain kooperatif menurut Nugraha (2004: 915) adalah permainan yang melibatkan sekelompok anak, dimana setiap anak mendapatkan peran dan tugas masing-masing yang harus dilakukan untuk mencapai tujuan.

Menurut Cartledge dan Mailbum (dalam Kibtiyah, 2006: 52), Bermain kooperatif adalah salah satu bentuk permainan, dalam bermain tersebut anak belajar bekerjasama untuk tujuan bersama, mereka mampu saling member semangat dan mendukung anak dalam tanggungjawab belajar baik pada diri mereka atau orang lain, mengunakan keterampilan sosial yang berhubungan dengan kelompok. Menurut Cartledge dan Milburn (1995: 153), bahwa bermain kooperatif berguna untuk meningkatkan interaksi sosial yang positif, meliputi: 1). Termasuk anak-anak yang melakukan kegiatan atau bermain dengan anak lain; 2). Berbagi dan bergantian dengan teman; 3). Menyentuh lembut anak-anak lain, membantu anak lain dalam kesulitan; dan 40. Berbicara tentang kekuatan teman daripada kelemahan teman.

Anak belajar dengan teman sebaya dalam kelompok, maka akan berkembang suasana terbuka, saling berinteraksi, dan saling membutuhkan untuk mencapai keberhasilan dengan tujuan bersama. Keberhasilan dalam belajar bermain kooperatif ini bukan sematamata ditentukan oleh kemampuan individu secara utuh, melainkan perolehan belajar itu akan semakin baik apabila dilakukan secara bersama-sama dalam kelompok belajar bekerjasama dengan baik.

Menurut Slavin (dalam Thobroni, 2015: 237) metode bermain kooperatif memiliki 6 karakteristik utama, yaitu:

1. Group goals (adanya tujuan kelompok)
2. Individual accountability (adanya tanggungjawab perorangan)

3. Equal opportunities for success ( adanya kesempatan yang sama untuk menuju ukses)

4. Team competition (adanya persaingan kelompok.

5. Task specialization (adanya proses penyesuaian diri terhadap kepentingan pribadi).

Tahapan kooperatif, menurut Wahyuningsih (2013: 17), tahapan di dalam setiap kegiatan pembelajaran yang mendukung proses dalam pembelajaran anak, berikut merupakan tahapan kooperatif:

Tabel 1 Tahapan Kooperatif

\begin{tabular}{ll}
\hline \multicolumn{1}{c}{ Fase-Fase } & \multicolumn{1}{c}{ Tingkah laku Guru } \\
\hline $\begin{array}{l}\text { Fase 1 : } \\
\text { Menyampaikan } \\
\text { tujuan dan } \\
\text { memotivasi } \\
\text { siswa }\end{array}$ & $\begin{array}{l}\text { Guru menyampaikan tujuan } \\
\text { pelajaran yang ingin dicapai } \\
\text { pada pelajaran tersebut dan } \\
\text { memotivasi siswa }\end{array}$ \\
\hline $\begin{array}{l}\text { Fase 2 : } \\
\text { Menyajikan }\end{array}$ & $\begin{array}{l}\text { Guru menyajikan informasi } \\
\text { kepada siswa dengan cara } \\
\text { demonstrasi atau melalui } \\
\text { bacaan }\end{array}$ \\
\hline $\begin{array}{l}\text { Fase 3 : } \\
\text { Mengorganisasi } \\
\text { kan siswa ke } \\
\text { dalam kelompok } \\
\text { belajar }\end{array}$ & $\begin{array}{l}\text { Guru menjelaskan kepada } \\
\text { siswa bagaimana caranya } \\
\text { belajar dan membantu setiap } \\
\text { kelompok agar melakukan } \\
\text { transisi secara efisien }\end{array}$ \\
\hline $\begin{array}{l}\text { Fase 4 : } \\
\text { Membimbing }\end{array}$ & $\begin{array}{l}\text { Guru membimbing } \\
\text { kelompok belajar pada saat }\end{array}$ \\
kelompok \\
bekerja dan \\
belajar
\end{tabular} $\begin{aligned} & \text { mereka mengerjakan tugas } \\
& \text { mereka }\end{aligned}$

Stahl (dalam Haenilah, 2015: 142) menyatakan bahwa "Proses bermain kooperatif ini mampu merangsang dan menggungah potensi anak secara optimal dalam suasana belajar pada 
kelompok-kelompok kecil terdiri dari 2 sampai 6 orang anak". Bermain kooperatif merupakan strategi pembelajaran yang menitikberatkan pada pengelompokan anak dengan karakteristik yang berbeda-beda ke dalam kelompokkelompok kecil. Di dalam kelompok dibangun iklim saling ketergantungan yang positif antara anak agar tercipta pembelaharan yang berkualitas. Berikut adalah contoh permainan dalam bermain kooperatif (Huda, 2015: 98): 1). Bermain Pembangunan (Bermain Balok); 2). Tikus dan Kucing; dan 3). Estafet Gelang Karet

\section{METODE PENELITIAN}

Penelitian ini menggunakan metode Penelitian Tindakan Kelas (PTK). Menurut Elliot (dalam Wina, 2010: 25), penelitian tindakan adalah kajian tentang situasi sosial dengan maksud untuk meningkatkan kualitas tindakan melalui proses diagnosis, perencanaan, pelaksanaan, pemantauan, dan mempelajari pengaruh yang ditimbulkannya. Penelitian Tindakan Kelas yang dilaksanakan di PAUD Ceria, Cikarang, Bekasi dilakukan pada bulan Agustus Tahun Ajaran 2018 - 2019. Adapun yang menjadi subjek dalam penelitian ini adalah anak Kelompok B yang berusia 5-6 tahun di PAUD Ceria Tahun Ajaran 2018 - 2019 yang berjumlah 8 anak terdiri dari 4 anak laki-laki dan 4 anak perempuan.

Desain penelitian menggunakan model Kemmis "spiral refleksi diri”" (dalam Sukidin, dkk, 2010: 48-49)

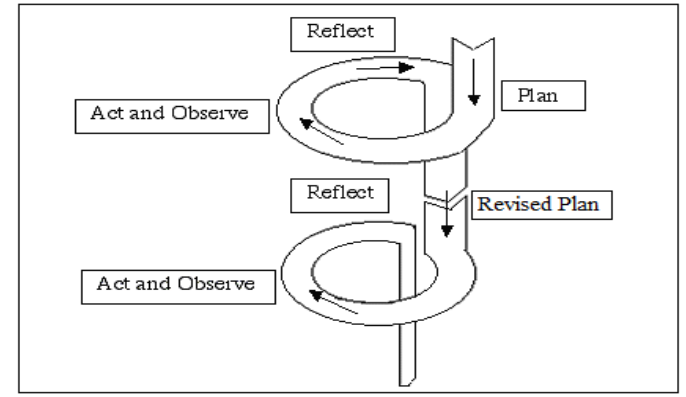

Gambar 1. Prosedur PTK

Adapun prosedur penelitian, berdasarkan desain penelitian di atas adalah sebagai berikut: Tahapan Perencanaan (Planning); Tahapan Pelaksanaan Tindakan (Act); Tahapan Observasi; dan, Tahapan Refleksi (Reflection).
Teknik pengumpulan data yang digunakan adalah observasi atau pengamatan yang dilakukan untuk melihat kemampuan bekerjasama anak usia 5-6 tahun melalui metode bermain kooperatif, serta Dokumentasi dalam bentuk Foto dan Video. Teknik analisis data yang digunakan adalah Teknik analisis data menurut Sugiyono (2011: 374), yaitu menyusun secara sistematis data yang diperoleh dari hasil observasi dan catatan lapangan sehingga dapat mudah dipahami dan temuannya dapat diinformasikan kepada orang lain.

Indikator keberhasilan, dalam penelitian ini adalah apabila minimal $80 \%$ dari semua jumlah anak sudah mampu melakukan indikatorindikator bekerjasama yang terdiri dari:

Tabel 2 Kriteria Ketuntasan

\begin{tabular}{|c|c|}
\hline Presentase Ketuntasan & Keterangan \\
\hline$>80$ & Sangat Baik \\
\hline$>60-80$ & Baik \\
\hline$>40-60$ & Cukup \\
\hline$>20-40$ & Kurang \\
\hline \multicolumn{2}{|r|}{ (dalam Widyoko, 2015:242) } \\
\hline
\end{tabular}

Data yang dianalisa dalam persentase menggunakan rumus:

$$
\begin{aligned}
& \mathrm{P}=\frac{\mathrm{F} \times 100 \%}{\mathrm{~N}} \\
& \text { Keterangan: } \\
& \mathrm{P}=\text { Angka Presentasi } \\
& \mathrm{F}=\text { Frekuensi aktivitas/skor anak } \\
& \mathrm{N}=\text { Jumlah anak dalam satu kelas }
\end{aligned}
$$

\section{HASIL DAN PEMBAHASAN}

Siklus I (tiga pertemuan)

Hasil pengamatan peningkatan kemampuan bekerjasama anak usia 5-6 tahun melalui metode bermain kooperatif pada Siklus I diuraikan dalam tabel, seperti berikut:

Tabel 3. Rekapitulasi Siklus I

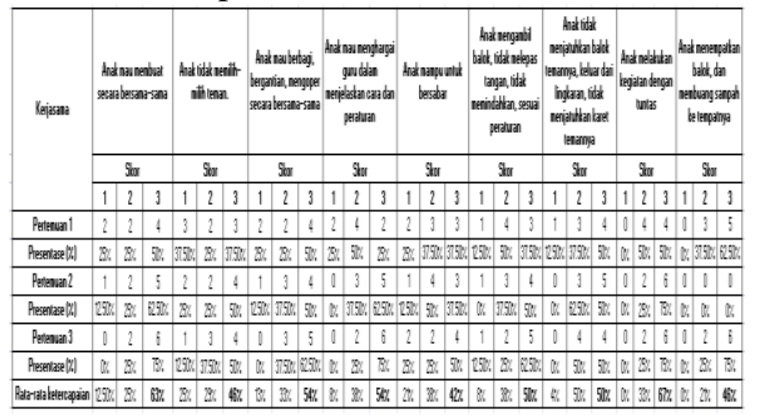




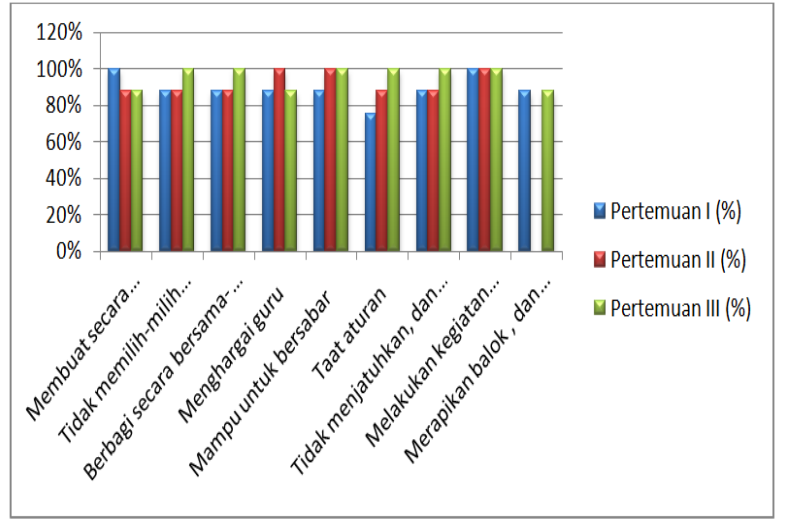

Gambar 1. Diagram Siklus I

Siklus II (tiga pertemuan)

Hasil pengamatan peningkatan kemampuan bekerjasama anak usia 5-6 tahun melalui metode bermain kooperatif pada Siklus II diuraikan menjadi tabel, seperti berikut:

Tabel 4. Rekapitulasi Siklus II

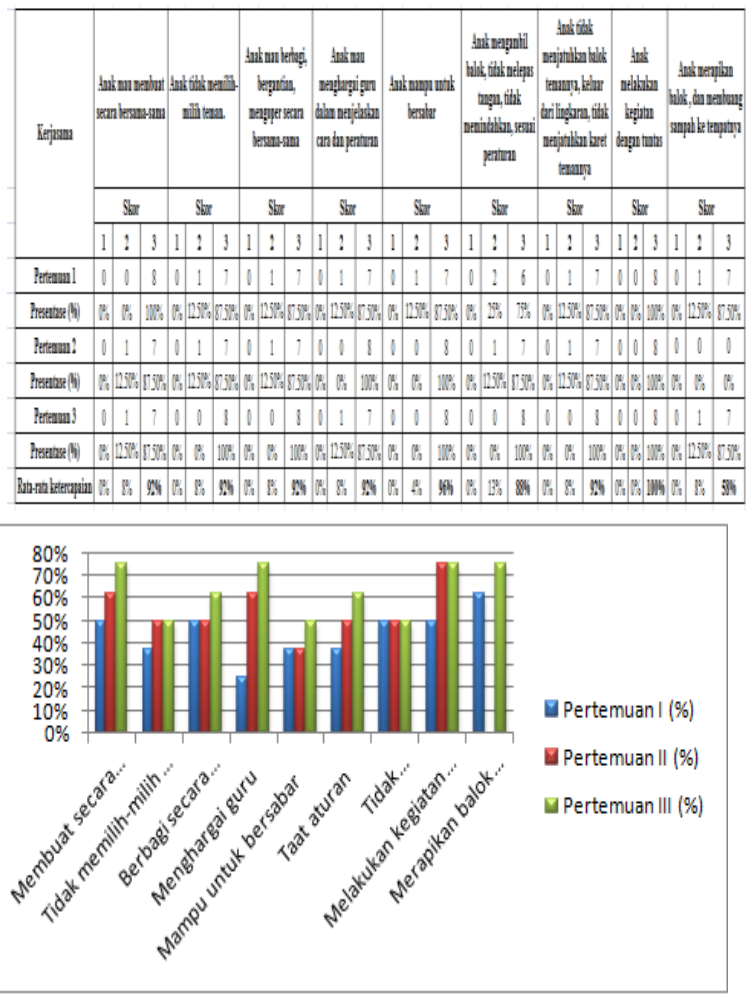

Gambar 2. Diagram Siklus II
Tabel 5. Persentase Kenaikan Setiap Siklus

\begin{tabular}{|c|c|c|c|c|}
\hline No & $\begin{array}{l}\text { Indikator } \\
\text { Penilaian } \\
\end{array}$ & $\begin{array}{c}\text { Hasil } \\
\text { Siklus I } \\
\end{array}$ & $\begin{array}{c}\text { Hasil } \\
\text { Siklus II } \\
\end{array}$ & $\begin{array}{c}\text { Pening- } \\
\text { katan }\end{array}$ \\
\hline 1. & $\begin{array}{l}\text { Anak mau } \\
\text { membuat secara } \\
\text { bersama-sama }\end{array}$ & $63 \%$ & $92 \%$ & $29 \%$ \\
\hline 2. & $\begin{array}{l}\text { Anak tidak } \\
\text { memilih-milih } \\
\text { teman. }\end{array}$ & $46 \%$ & $92 \%$ & $46 \%$ \\
\hline 3. & $\begin{array}{l}\text { Anak mau } \\
\text { berbagi, } \\
\text { bergantian, } \\
\text { mengoper } \\
\text { secara bersama- } \\
\text { sama }\end{array}$ & $54 \%$ & $92 \%$ & $38 \%$ \\
\hline 4. & $\begin{array}{l}\text { Anak mau } \\
\text { menghargai } \\
\text { guru dalam } \\
\text { menjelaskan } \\
\text { cara dan } \\
\text { peraturan }\end{array}$ & $54 \%$ & $92 \%$ & $38 \%$ \\
\hline 5. & $\begin{array}{l}\text { Anak mampu } \\
\text { untuk bersabar }\end{array}$ & $42 \%$ & $96 \%$ & $54 \%$ \\
\hline 6. & $\begin{array}{l}\text { Anak } \\
\text { mengambil } \\
\text { balok, tidak } \\
\text { melepas tangan, } \\
\text { tidak } \\
\text { memindahkan, } \\
\text { sesuai peraturan }\end{array}$ & $50 \%$ & $88 \%$ & $38 \%$ \\
\hline 7. & $\begin{array}{l}\text { Anak tidak } \\
\text { menjatuhkan } \\
\text { balok temannya, } \\
\text { keluar dari } \\
\text { lingkaran, tidak } \\
\text { menjatuhkan } \\
\text { karet temannya } \\
\end{array}$ & $50 \%$ & $92 \%$ & $42 \%$ \\
\hline 8. & $\begin{array}{l}\text { Anak } \\
\text { melakukan } \\
\text { kegiatan dengan } \\
\text { tuntas }\end{array}$ & $67 \%$ & $100 \%$ & $33 \%$ \\
\hline 9. & $\begin{array}{l}\text { Anak } \\
\text { menempatkan } \\
\text { balok dan } \\
\text { membuangsamp } \\
\text { ah ketempatnya }\end{array}$ & $46 \%$ & $58 \%$ & $12 \%$ \\
\hline 10. & $\begin{array}{l}\text { Anak mau } \\
\text { membuat secara } \\
\text { bersama-sama }\end{array}$ & $50 \%$ & $92 \%$ & $42 \%$ \\
\hline \multicolumn{2}{|c|}{$\begin{array}{l}\text { Total Peningkatan } \\
\text { Siklus I dan II }\end{array}$} & & $33 \%$ & \\
\hline
\end{tabular}




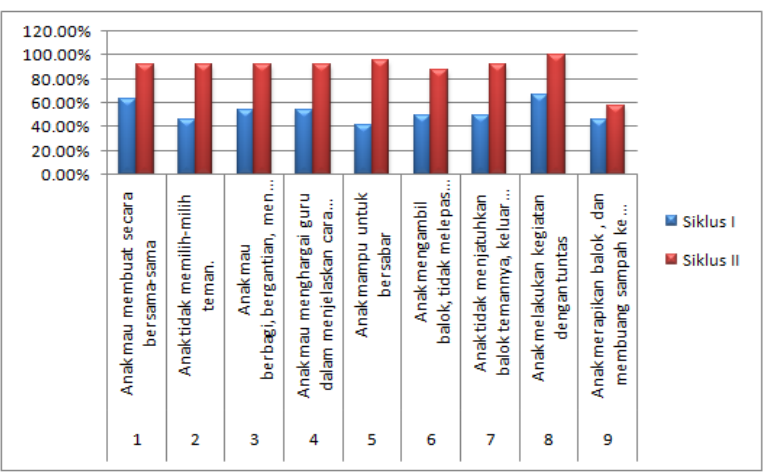

Gambar 3. Diagram Persentase Kenaikan Setiap Siklus

Berdasarkan data yang diperoleh pada Siklus II, dapat dikatakan bahwa tindakan yang dilakukan telah berhasil meningkatkan kemampuan sosial emosional anak karena nilai yang diperoleh anak sudah melebihi target yang telah ditentukan pada indikator keberhasilan di atas 80. Ketercapaian ini diperoleh karena kegiatan bermain kooperatif merupakan kegiatan bermain yang cukup menarik bagi anak sehingga membuat kegiatan pembelajaran lebih menyenangkan. Adanya motivasi dari guru dan reward yang diberikan peneliti menambah semangat anak untuk mengikuti pembelajaran.

Ketercapaian ini diperoleh dalam tujuan aspek perkembangan sosial emosional yaitu kemampuan bekerjasama melalui metode bermain kooperatif. Berdasarkan keterangan di atas maka bermain balok; bermain tikus dan kucing; dan bermain estafet gelang karet bertujuan untuk mengembangkan aspek sosial emosional anak seperti mengembangkan kemampuan kerjasama dengan indikator, anak mampu bersikap kooperatif dengan teman (anak mau membuat secara bersama-sama), anak bermain dengan teman sebaya (anak tidak memilih-milih teman), anak mampu berbagi dengan orang lain (anak mau berbagi, bergantian, mengoper secara bersama-sama), anak dapat menghargai hak/ pendapat/ karya orang lain (anak mau menghargai guru dalam menjelaskan cara dan peraturan dan anak mampu untuk bersabar), anak dapat mentaati aturan kelas kegiatan, aturan (anak mengambil balok, tidak melepas tangan, tidak memindahkan, sesuai peraturan dan anak tidak boleh menjatuhkan balok temannya, keluar dari lingkaran, tidak menjatuhkan karet temannya), anak dapat bertanggungjawab atas perilakunya untuk kebaikan diri sendiri (anak melakukan kegiatan dengan tuntas, dan anak menempatkan balok, dan membuang sampah ke tempatnya). Ini sesuai dengan yang telah dijelaskan dalam Permendikbud No. 137 Tahun 2014 tentang Standar Pendidikan Anak Usia Dini dalam standar pencapaian perkembangan anak, sesuai dengan kompetensi dasar perkembangan sosial emosional anak usia 5-6 tahun.

Menurut Nugraha dan Yeni (2009: 9.15), bermain kooperatif adalah permainan yang melibatkan sekelompok anak, dimana setiap anak mendapatkan peran dan tugas masingmasing yang harus dilakukan untuk mencapai tujuan bersama. Permainan kooperatif ini mengajarkan anak bersikap sportif dan bekerjasama untuk mencapai tujuan. Manfaat permainan kooperatif ialah dapat mengajarkan anak bersikap sportif dan bekerjasama untuk mencapai tujuan tertentu, juga hal ini baik dilakukan untuk mengembangkan keterampilan sosial. Kelebihan yang terjadi pada ketiga permainan ini dapat menutupi kekurangan pada permainan kooperatif ini.

Untuk mencapai keberhasilan dalam indikatorindikator di atas, pada siklus I pembelajaran kooperatif dilakukan melalui kegiatan bermain kooperatif dengan bermain balok (setiap anak mendapat 5 buah balok); bermain tikus dan kucing; bermain estafet gelang karet. Pada siklus kedua, kegiatan kemampuan sosial emosional anak ditingkatkan dengan melakukan permainan yang sama dengan Siklus I. Namun, untuk kegiatan tambahan yang membedakan adalah jumlah variasi bermain balok bertambah menjadi 10 balok per-anak; menggunakan variasi kartu pada permainan tikus dan kucing; serta jumlah variasi bertambah menjadi 15 karet pada permainan estafet gelang karet.

Adapun hasil peningkatan pada Siklus I ratarata ketercapaian anak mau membuat secara bersama-sama yaitu sebesar $63 \%$; rata-rata ketercapaian anak tidak memilih-milih teman.yaitu sebesar $46 \%$; rata-rata ketercapaian anak mau berbagi, bergantian, mengoper secara bersama-sama yaitu sebesar 54\%; rata-rata 
ketercapaian anak mau menghargai guru dalam menjelaskan cara dan peraturan yaitu sebesar 54\%; rata-rata ketercapaian anak mampu untuk bersabar yaitu sebesar $42 \%$; rata-rata ketercapaian anak mengambil balok, tidak melepas tangan, tidak memindahkan, sesuai peraturan yaitu sebesar 50\%; rata-rata ketercapaian anak tidak menjatuhkan balok temannya, keluar dari lingkaran, tidak menjatuhkan karet temannya yaitu sebesar $50 \%$; rata-rata ketercapaiananak melakukan kegiatan dengan tuntas yaitu sebesar $67 \%$; ratarata ketercapaian anak menempatkan balok, dan membuang sampah ke tempatnya yaitu sebesar $46 \%$.

Pada Siklus II, rata-rata ketercapaian anak mau membuat secara bersama-sama yaitu sebesar $92 \%$; rata-rata ketercapaian anak tidak memilihmilih temannya itu sebesar $92 \%$; rata-rata ketercapaian anak mau berbagi, bergantian, mengoper secara bersama-sama yaitu sebesar 92\%; rata-rata ketercapaian anak mau menghargai guru dalam menjelaskan cara dan peraturan yaitu sebesar $92 \%$; rata-rata ketercapaian anak mampu untuk bersabar yaitu sebesar 96\%; rata-rata ketercapaian anak mengambil balok, tidak melepas tangan, tidak memindahkan, sesuai peraturan yaitu sebesar $88 \%$; rata-rata ketercapaian anak tidak boleh menjatuhkan balok temannya, keluar dari lingkaran, tidak menjatuhkan karet temannya yaitu sebesar $92 \%$; rata-rata ketercapaian anak menyelesaikan kegiatan dengan selesai yaitu sebesar 100\%; rata-rata ketercapaian anak merapikan balok, dan membuang sampah ke tempatnya yaitu sebesar 58\%. Peningkatan dari Siklus I ke Siklus II sebanyak $33 \%$.

Pada proses pembelajaran, anak dilibatkan secara langsung dalam kegiatan bermain balok, bermain tikus dan kucing, dan bermain estafet gelang karet. Media yang digunakan dalam kegiatan ini pun melalui anak sendiri dan beberapa media yang lebih memudahkan anak dalam menerima dan memahami pembelajaran. Ini didasarkan pada prinsip anak usia dini yaitu bermain seraya belajar. Melalui kegiatan bermain balok, bermain tikus dan kucing, dan bermain estafet gelang karet yang memiliki kebermaknaan, bukan hanya kesenangan yang didapat oleh anak tetapi juga sikap kebersamaan anak, sosial anak, kerjasama anak dengan teman-temannya dalam pembelajaran, karena sebelumnya proses pembelajaran hanya terpaku pada majalah, buku tulis, pensil dan permainan yang sudah ada di outdoor.

\section{SIMPULAN DAN SARAN}

Berdasarkan hasil data yang diperoleh dapat disimpulkan bahwa terdapat peningkatan dalam kemampuan bekerjasama anak usia 5-6 tahun melalui pembelajaran kooperatif. Terjadinya peningkatan tersebut dikarenakan dalam mengenalkan kerjasama pada anak dengan metode pembelajaran kooperatif belum pernah diterapkan melalui permainan. Selain itu, dalam merencanakan metode pembelajaran kooperatif ini masing-masing permainan memiliki kelebihan dan kekurangan, belajar bagaimana melatih kesabaran, saling bertukar ide atau imajinasi, belajar bagaimana cara berkomunikasi dengan teman, saling jujur, belajar sportif di dalam kelompok, belajar berbagi, menghargai keputusan teman, belajar bagaimana mentaati aturan dan bertanggungjawab di dalam kelas, sehingga anak mampu bergabung bersama temantemannya ketika bermain.

Kemudian salah satu faktor pendukung meningkatnya kerjasama anak usia 5-6 tahun melalui pembelajaran kooperatif ini yaitu adanya reward berupa gambar bintang. Reward diberikan kepada anak untuk meningkatkan semangat, motivasi dan antusias anak dalam melakukan kegiatan.

Berdasarkan hasil penelitian tersebut, saran yang dapat diberikan bagi guru, yaitu: pertama, Kegiatan bermain kooperatif hendaknya dikaitkan dengan tema pembelajaran, sehingga tujuan pelaksanaan pembelajaran yang akan dicapai terlihat lebih jelas; kedua, kegiatan bermain tikus dan kucing, serta estafet gelang karet dilakukan di luar ruangan agar anak lebih leluasa di dalam bermain; ketiga, reward yang diberikan kepada anak sebaiknya lebih bervariatif, misalnya stiker dengan bentuk lain seperti stiker senyum, makanan kesukaan anak snack ringan, alat tulis, dan sebagainya. Hal ini bertujuan agar anak dapat meningkatkan lagi semangat dan antusiasnya dalam kegiatan.

Adapun saran yang dapat diberikan bagi kepala sekolah, adalah agar kepala sekolah menstimulasi kemampuan bekerjasama anak 
dengan menyediakan berbagai kegiatan bermain diserta media pembelajaran yang bervariasi.

\section{DAFTAR PUSTAKA}

Arikunto, S. (2006). Prosedur penelitian suatu pendekatan praktik. Jakarta: Rineka Cipta.

Asmawati, L. (2008). Dasar-dasar pendidikan anak usia dini secara Islami. Jakarta: STIT Insida.

Haenilah, E.Y. (2015). Kurikulum dan pembelajaran PAUD. Media Akademi: Yogyakarta.

Huda, M. (2015). Peneltian tindakan kelas teori dan praktik. Yogyakarta. Pustaka Pelajar.

Julia, J. (2017). Pendidikan musik: permasalahan dan pembelajarannya. Sumedang. UPI Sumedang Press.

Nasution, S. (2010). Sosiologi Pendidikan. Jakarta: Bumi Aksara.
Patmonodewo, S. (2003). Pendidikan anak prasekolah. Jakarta: PT. Rineka Cipta.

Rasyid, H., dkk. (2009). Asesmen perkembangan anak usia dini. Yogyakarta: Multi Pressindo.

Slavin, R.E. Cooperative learning. Bandung. Nusa Media.

Sugiharyanto. (2007). Geografi dan sosiologi. Semarang. Yudhistira.

Suyanto, S. (2005). Dasar-dasar pendidikan anak usia dini. Yogyakarta. Hikayat Publishing.

Thobron, M. (2015). Belajar dan pembelajaran teori dan praktik. Yogyakarta: Ar-Ruzz Media. 